\title{
Institutional entrepreneurship and techniques of inclusiveness in the creation of the Intergovernmental Platform on Biodiversity and Ecosystem Services
}

\author{
Isabelle Arpin $^{1,2}$, Marc Barbier $^{3,4,5,6,7,8}$, Guillaume Ollivier $^{4,9}$ and Celine Granjou $^{1,2,10}$
}

\begin{abstract}
This article contributes to understanding the conditions of social-ecological change by focusing on the agency of individuals in the pathways to institutionalization. Drawing on the case of the Intergovernmental Platform on Biodiversity and Ecosystem Services (IPBES), it addresses institutional entrepreneurship in an emerging environmental science-policy institution (ESPI) at a global scale.
\end{abstract}

Drawing on ethnographic observations, semistructured interviews, and document analysis, we propose a detailed chronology of the genesis of the IPBES before focusing on the final phase of the negotiations toward the creation of the institution. We analyze the techniques and skills deployed by the chairman during the conference to handle the tensions at play both to prevent participants from deserting the negotiations arena and to prevent a lack of inclusiveness from discrediting the future institution. We stress that creating a new global environmental institution requires the situated exercise of an art of "having everybody on board" through techniques of inclusiveness that we characterize.

Our results emphazise the major challenge of handling the fragmentation and plasticity of the groups of interest involved in the institutionalization process, thus adding to the theory of transformative agency of institutional entrepreneurs. Although inclusiveness might remain partly unattainable, such techniques of inclusiveness appear to be a major condition of the legitimacy and success of the institutionalization of a new global ESPI. Our results also add to the literature on boundary making within ESPIs by emphasizing the multiplicity and plasticity of the groups actually at stake.

Key Words: chair person; environmental science-policy institutions; institutional entrepeneurship; IPBES (Intergovernmental Platform on Biodiversity and Ecosystem Services); sociological investigation; techniques of inclusiveness

INTRODUCTION AND THEORETICAL BACKGROUND In the context of major environmental challenges now often associated with the Anthropocene (Crutzen 2002), innovative changes are critically needed to cope with the unprecedented impacts on and threats to social-ecological systems (SESs). Political and institutional changes, including the creation of new institutions that could address major global changes, are often called for (Biermann at al. 2012). However, more grounded insights and feedback are needed on the conditions of establishment of such institutions and how they can efficiently foster social-ecological change. This article aims to shed light on the conditions of creation of a new international environmental science-policy institution (ESPI): the Intergovernmental Platform on Biodiversity and Ecosystem Services (IPBES). During our investigation of the construction of the IPBES, Bob Watson, chairman of the official conferences of creation of the institution, turned out to play a major and very conspicuous role in the difficult process of handling the divides and tensions among the various participants: he contributed significantly to the successful conclusion of a long-lasting institutionalization process. Building on the analysis of his role of institutional entrepreneur (DiMaggio 1988) in the IPBES construction, we aim to refine the understanding of the transformative agency of individuals in the pathways to global institutionalization.

Our aim is to contribute to the research program put forward by Westley et al. (2013:1) by providing "empirically based insights into the kinds of agency that make transformation ... possible" and refining "our understanding of the vital impact that individuals can have in these processes." However, whereas Westley et al. (2013) studied the transformation of local SESs, our focus is on the creation of an international institution meant to address the decline of global biodiversity and to better monitor and manage ecosystems. Although the system we observe is a social one, it is tightly linked to on-going ecological changes (biodiversity loss, ecosystem degradation), which it aims to address and influence.

Often presented as "the IPCC (Intergovernmental Panel on Climate Change) for biodiversity" (e.g., Nature 2010), the IPBES can be considered a major cornerstone in the tranformation of the international environmental governance following the Millennium Ecosystem Assessment (MA 2005). It contributes indeed to a new focus on the notion of ecosystem services, i.e., the services people derive from ecosystems, such as pollination or water supply. Although the will to articulate and build new proximities between nature conservation and social development is much older (this has been the objective of the notion of sustainable development), the release of the MA report in 2005 has contributed to focusing on the notion of ecosystem services to bring ecological and social dimensions together. As proposed by Vadrot $(2014 a)$, the conceptualization of this global paradigm of valorization has played an important role in the IPBES creation. Here we propose an account of the efforts to include various scientific and political groups of interest in the type of environmental organizations that the notion of ecosystem services has, at least partly, brought to life. 
The IPBES creation process was rooted in a strong will for "strengthening the biodiversity science/policy interface" (Babin 2008) but raised strong uncertainties about the modus operandi of the interface. Although science and policy certainly constitute two different social worlds with their own aims, practices, and criteria of legitimacy and credibility, science and policy studies have cogently shown that these worlds interact and intersect constantly, such that their boundary should not be considered given: instead, it is constantly made and reshaped (Jasanoff 1990). How was the science-policy boundary negotiated and articulated during the creation of IPBES? Which techniques and strategies were used by the IPBES promoters to handle the inevitable tensions and conflicting demands of the scientific and political communities as well as their internal fragmentation? Although much has been written about how the IPBES ought to be organized and managed to be efficient, credible, and legitimate (e.g., Van den Hove and Chabason 2009, Koetz et al. 2011, Vohland et al. 2011, Perrings et al. 2011, Turnhout et al. 2012), little is known about how its promoters have attempted to address, in practice, the major challenge of managing the diversity and internal heterogeneity of the various groups of interest involved in building a global ESPI.

To address these questions, we will explore the process of institutional entrepreneurship that led to the emergence of the IPBES as a global and inclusive institution. As highlighted by Lawrence et al. (2001) in their pionneering work, a focus on institutional entrepreneurship is useful to understand the emergence of institutions because the absence of stabilized institutional patterns and the prevailing uncertainties at an early stage of the negotiations give leeway to individuals in leading positions (see also Fligstein 1997 and Maguire et al. 2004). Organization theory showed that the birth and early development of organizations require paying attention to how dualities and tensions are managed in the institutionalization process (Kimberly 1979, Young 1991, Lewis 2000). Here the detailed socio-ethnographical account we offer will show how a key institutional entrepreneur, Bob Watson, sought to handle the tensions and build inclusiveness. However, rather than presenting the IPBES creation process as a success story of consensus building, we intend to show how various types of tensions regarding the legitimacy and agency of the future institution were addressed and mitigated rather than solved.

Tracey et al. (2010:60) have insisted on the "multilevel nature of bridging institutional entrepreneurship, showing that it entails institutional work at the micro-, meso-, and macrolevels." Here we focus on the micro level of institutional entrepreneurship during the final phase of the IPBES creation. This ultimate phase had to address many of the previous achievements, unaccomplishments, and shortcomings of previous phases of negotiation to perform an irreversible closure of a process that had lingered for many years. Vadrot $(2014 a, 2014 b)$ analyzed the IPBES creation in terms of epistemic selectivities, meaning the mechanisms within political institutions that favor specific forms of knowledge, problem perceptions, and narratives over others. Our account of the IPBES creation does not focus on such logics of power in the mobilization of knowledge within committees and boards: instead, it seeks to provide an organizational reading emphasizing how a major institutional entrepreneur handled a range of techniques of inclusiveness to address the tensions between shifting groups of interest and to create a global institution that could be regarded as inclusive.

Here we do not consider inclusiveness as a standard against which we would assess the level of achievement of the institutionalization process. Although inclusiveness might remain partly unattainable, we argue that the techniques deployed by the chairman to achieve it were a crucial condition of the legitimacy and success of the IPBES creation.

\section{METHODS}

We resorted to various methods to document the IPBES construction process. First of all, one of the authors had the opportunity to be part of the French delegation attending the meeting in Panama from April 16th to 21st, 2012, which aimed to determine modalities and institutional arrangements of the future institution. Being on the official list of French delegates enabled her to act both as a participant (her opinion regarding the mobilization of indigenous or traditional ecological knowledge was asked a couple of times) and as an observer documenting and analyzing the negotiations. She also had informal discussions with European delegates, including scientists as well as political and nongovernmental organization representatives, and asked them about the reasons got their involvement in the IPBES construction, their opinion on the conference, and their job. She did not interview Bob Watson, but she could observe his behavior as chairman during the plenary sessions and European Union (EU) coordination meetings. Attending the conference yielded very rich empirical material on which this article heavily draws: although an important part of negotiations undoubtedly takes place behind the scenes, a conference is a good place to observe how the organization promoters can develop an art of handling tensions so as to regularly reassert their will to have everybody on board.

In addition, our results build on 15 semistructured interviews carried out with French scientists and international staff of the United Nations Environment Programme (UNEP) and the the International Union for Conservation of Nature (IUCN), selected because of their strong involvement in the IPBES construction process. The interviews were realized from 2008 to 2011 and were recorded and transcribed. Observations and interviews were eventually backed up with a documentary survey to exploit the many documents issued by the IPBES on its website (http://www.ipbes.net/).

We used qualitative data analysis software (MAXQDA) to analyze our material to depict the meanings, tensions, and consensus elaborated by the actors in context, according to the principles of situational analysis (Clarke 2005). Our approach is in line with a political science perspective that draws on Weberian sociology and considers that to "explain an outcome is to understand ... how things came to be the way they were and not some other way" (Hay 2011:172): our role as social scientists is to bring into light a grounded understanding of how actors' understandings are themselves shaped by resources, interactions, and contingencies. MAXQDA helped us to go through all the texts available (interview transcripts and conference observation notes: about 300 pages in total) in a systematic manner and to code themes relevant for the analysis, i.e., mark the passages which referred to the same tension or technique of inclusiveness. Although the tensions could already be detected during the 
conference, the systematic analysis of the material enabled us to characterize them in details and also to identify and characterize the techniques of inclusiveness used by the chairman.

With Westley et al. (2013), we think that the identification of transformative agency and skills should be carried out in relationship with the understanding of the type and context of SES change. In the next section, we shall present a diachronic account of the IPBES construction process before characterizing the institutional entrepreneurship at work in the final phase of the negotiations. The results regarding tensions and techniques mostly draw on the conference notes, whereas the diachronic account mostly builds on interviews and the documentary survey.

\section{RESULTS}

\section{A diachronic and synthetic account of the IPBES creation process}

Drawing on our investigation and the literature (notably Görg et al. 2010 and Larigauderie and Mooney 2010), we identified three main stages in the genesis of the IPBES until its first plenary session in January 2013 (see Fig. 1). Using the TimeGlider online interface (http://timeglider.com/), we elaborated a typology of the main events that had been identified and informed through a documentary survey. This type of methodology has strong relevance for longitudinal studies in science and technology (Callon 1991, Law and Callon 1992) and for organization studies (Pettigrew 1990, Van de Ven and Poole 1990) on negotiation processes. The result of this document analysis is available online (https://figshare.com/articles/IPBES events/2063205).

First stage (early 1990s-mid 2000s)

During this stage, the failure to achieve effective conservation of biodiversity and ecosystems was increasingly viewed as the consequence of the gap between science and policy rather than of a lack of knowledge ( Barbault and Le Duc 2005, Watson 2005; interviews). This conviction was both linked to the success of the IPCC in turning climate change into a major political concern (Miller 2006) and to the fact that the Subsidiary Body on Scientific, Technical and Technological Advice was found to be unable to bring an equivalent scientific input to the Convention on Biological Diversity compared with IPCC for the United Nations Framework Convention on Climate Change (Koetz et al. 2008). In this context, leaders of biodiversity research, including leaders of the international program Diversitas, gradually arrived at the conclusion that they needed a science-policy interface to really wield political influence. In the early 1990s the Global Environmental Facility was convinced by the chair of its Scientific and Technical Advisory Panel, Robert Watson, and other scientists to fund a large assessment of biodiversity at the global scale, the Global Biodiversity Assessment. The Global Biodiversity Assessment was chaired by Bob Watson (Heywood 1995) but was rejected by the political world. This was an important milestone because it clearly showed biodiversity scientists that what they considered a scientific achievement could be a political failure, jeopardizing their capacity to attract the resources and establish the alliances needed to foster and maintain a transformation of the existing environmental governance. This contributed to convincing the leaders of biodiversity science that a genuinely international body involving scientists and policy makers was indispensable; otherwise, their capacity to attract the resources and establish the alliances needed to foster and maintain
Fig. 1. Stages of the making of the Intergovernmental Platform on Biodiversity and Ecosystem Services (IPBES). IMoSEB = International Mechanism on Scientific Expertise on Biodiversity.

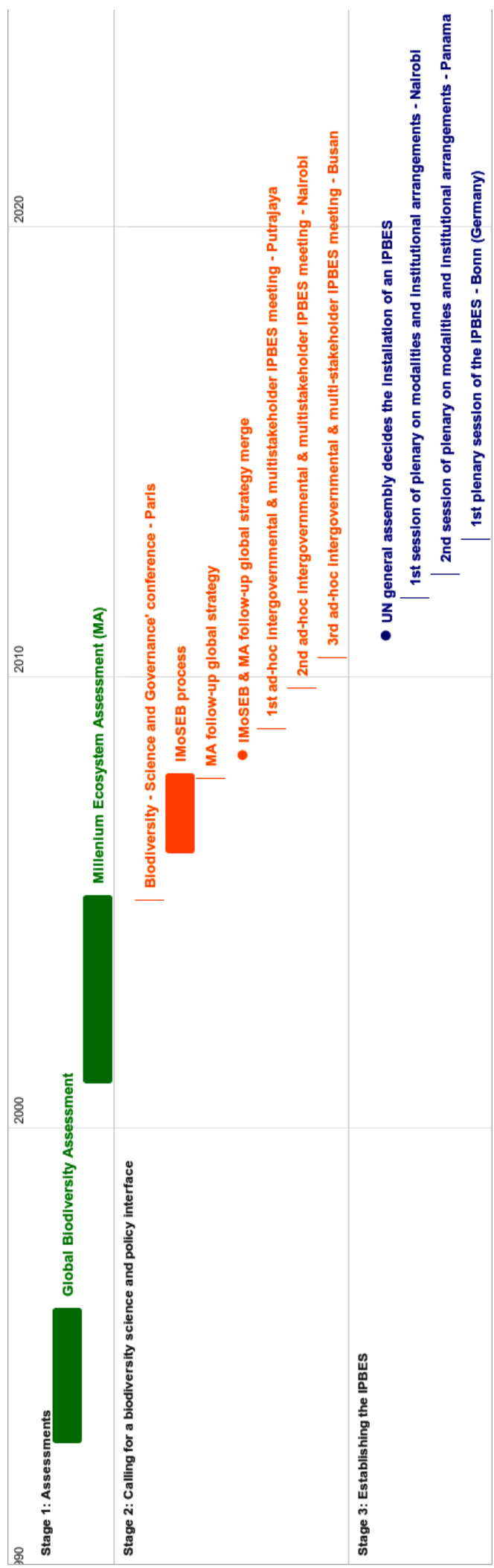


a transformation of the existing environmental governance would be jeopardized. This contributed to convincing the leaders of biodiversity science that global biodiversity asessments must be demand driven and codesigned by scientists and policy makers to gain political influence (interviews).

Second stage (mid 2000s-2008)

This stage was characterized by the emergence and progressive coming together of two initiatives in favor of the creation of a new science policy interface (UNEP 2008). A major ecosystem assessment, the Millennium Ecosystem Assessment (MA) was released in 2005 (MA 2005). The MA follow-up activities developed under the auspices of UNEP and led to a global strategy for turning knowledge into action. On the other hand, a consultative process toward an International Mechanism on Scientific Expertise on Biodiversity (IMoSEB) was implemented following the international Biodiversity, Science and Governance conference held in Paris in January 2005 that was closed with a call by French President Chirac for an "IPCC for biodiversity." The IMoSEB and the MA follow-up global strategy merged in the spring of 2008 in the IPBES brought by UNEP. Moreover, at the end of the 2000s, it was clear that the goal to halt biodiversity loss by the end of the decade had not been reached (Secretariat of the Convention on Biological Diversity 2010) so that a need was felt for new policies and institutions.

\section{Third stage (2008-2013)}

A series of intergovernmental meetings were convened under the auspices and the procedural rules of the United Nations (UN) to decide whether or not the IPBES should be established (UNEP 2009). UNEP interviewees initially assumed that the IPBES would be established by the end of 2010, declared the International Year of Biodiversity by the UN. The third meeting, convened in Busan, South Korea, in June 2010, led to an official agreement known as the Busan outcome (UNEP 2010). The Busan outcome identified four functions for IPBES: knowledge generation, assessments, policy support, and capacity building. In December 2010, the UN General Assembly decided the installation of an IPBES and requested that the platform be operationalized at the earliest opportunity. However, two more meetings were necessary to determine the platform's modalities of work and institutional arrangements, i.e., governance structure, rules of procedure, location of secretariat, etc. Substantial progress was made at the Panama conference. On its last day (April 21, 2012), the parties finally decided to establish the IPBES and to locate its secretariat in Bonn, Germany. They also decided that the plenary would have two subsidiary bodies: an administrative bureau and a multidisciplinary expert panel. However, they still had to address several important aspects at the first full session of the platform's plenary, which was held in Bonn in January 2013.

In bringing into conversation the adaptive cycle of SESs elaborated by Holling (1986) and the theory of opportunity context for social movements proposed by Dorado (2005), Westley et al. (2013) identified three phases of change in SESs corresponding both to various degrees of facility for change and innovation, and to various types of transformative agency: a phase of preparing for change (i.e., a moment of stability of physical and institutional structures, in which change is about challenging the existing order); a phase of navigating the transition (a moment of turbulent change facilitating novelty and innovation, in which transformation is about reinterpreting and creating organizations, understandings and beliefs); and a phase of building resilience of the new regime (a moment leading to a new configuration of stability, in which change is linked to the disappearance of some previous options and the building of tighter alliances between existing organizations, understandings, and beliefs).

The first stage of the IPBES genesis can be considered a phase of relative stability of the environmental governance, in which some scientists attempted to challenge the existing order - in vain. The second stage, opened up by the MA and the IMoSEB consultative process, was characterized by the involvement of various groups and actors (not only scientists but also policy makers and stakeholders) and the articulation of a range of proposals to reform the existing global SES of biodiversity (Babin 2008): it corresponds to a phase of navigating the transition. The third phase was marked by a narrowing down of the reform options, with the role of leader taken up by UNEP and the progressive focus on a certain type of organizational pattern, including the name of the IPBES: "Some ideas will inevitably be orphaned, but with successful brokering, resources may be consolidated around a coherent and innovative alternative.... At the same time, the reduction in the multiplicity of organizational forms signals the arrival of a new stable ... phase" (Westley et al. 2013:11). We will focus on this phase of building a new regime and its resilience in studying how the IPBES promoters, especially the conference chairman Robert Watson, handled the diversity and fragmentation of the various groups of interest involved in the negotiations during the final meeting in Panama in April 2012. We will emphazise the techniques of inclusiveness used by this institutional entrepreneur, which were essential to building the legitimacy of the global institution to come.

\section{Everybody on board?}

It eventually took several years, from 2008 to 2012, to establish the IPBES. One delegate familiar with intergovernmental environmental negotiation processes said in Panama: "we have been discussing for five years now; it is getting ridiculous, grotesque." The duration of the process has notably to do with the major challenge of managing the diversity and internal fragmentation of the IPBES stakeholders and representatives. We shall here briefly characterize three tensions at play that our investigation suggested were pervasive issues of friction during the Panama conference and more broadly during the whole process. These tensions reveal a fragmentation within scientific and political communities that tends to be at least as strong as the science-policy divide.

\section{Three types of pervasive tensions}

The temporality of the IPBES creation process is the first issue that raised long-standing tensions. Despite recurrent declarations during the plenary session such as at the earliest opportunity, as soon as possible, in the quickest way as possible, etc. (conference notes), there was a clear distinction between government representatives and science representatives. The former were begging for more time to examine the utility of creating a new 
institution and every possible option of organization, whereas the latter were bitterly complaining about the sluggishness of the process compared with the rhythms of environmental degradation ("we're going nowhere," informal discussion with a French scientist during the Panama conference who favored a quicker institutional process to address the urgent depletion of biodiversity). Many science representatives expressed frustration at the meeting that the IPBES was still not established and showed impatience because political representatives kept requesting more time to discuss specific options. On the other hand, representatives of countries (mostly Southern countries, including China) often criticized what they considered to be premature decisions:

Why so much pressure to establish something in this meeting? We should go slowly, step by step. (Chief of Bolivian delegation, Panama conference, plenary session, April 19, 2012)

The definition of regions that would be relevant to the future IPBES work is another issue that raised many tensions. Given the spatial heterogeneity of biodiversity and biodiversity issues, there was an acknowledged need to regionalize the platform's work. The possibility to regionalize its organization by establishing different IPBES centers was even considered at one stage, before being abandoned. Unlike the IPCC, which "rediscovered the local" long after its creation (Jasanoff and Long Martello 2004), the IPBES had to consider local issues, perspectives, and knowledge from the outset. Here, science and government representatives tended to be respectively in faour of mobilizing biogeographical criteria and political criteria, so that we basically have the usual major science-policy divide. However, things turned out to be more complicated. For instance, during the negotiations, several delegations defended the choice of IUCN regions, which they believed to be defined on a biogeographical basis and likely to contribute to the IPBES scientific credibility, until an IUCN delegate explained that it was more intricate (IUCN regions are based on a mix of criteria). The official discussions revealed that there are several ways of defining ecoregions. Interestingly, the representatives of some countries, including Fidji, Brazil, and Pakistan, defended biogeographical regions because they were more in line with their strategies than some political divides of the globe; for instance, Pakistan is united with China in the IUCN map, whereas it is united with Afghanistan in the UN map. The regionalization issue thus showed the internal divides of the policy and science communities.

The knowledge forms to be involved in the future IPBES are the third issue of long-lasting tension, already present before the IPBES in the Convention on Biological Diversity. They had been discussed for several years (e.g., Turnhout et al. 2012, Vadrot $2014 b$ ), with some participants advocating to rely solely on peerreviewed science and others arguing in favor of the integration of other knowledge forms. government representatives from many countries, notably Southern ones (Brazil, Mexico) but also Scandinavian countries (for more details on Nordic countries' view regarding indigenous knowledge, see Tunon et al. 2015), have been fully in favor of involving other forms of knowledge and especially Indigenous and local knowledge. Indeed, European delegates informally told us that Southern countries are very wary of Northern countries continuing to exert their domination through science in international organizations. However, several scientists and IUCN interviewees explained that they had difficulties dealing with other forms of knowledge, because the peer review process constitutes the cornerstone of their credibility and it remains unclear how these other forms of knowledge would be assessed and validated. They tend to consider the inclusion of non-peer-reviewed knowledge to be a threat to scientific credibility. In private, some natural scientists attending the Panama conference expressed very strong and blunt opinions about other forms of knowledge, such as "here they go again with this 'other knowledge holders' stuff, all this bullshit" or in a milder tone, "placing traditional knowledge holders and scientists on an equal footing is unacceptable; for us, this is a red line. It is not that we want to exclude these people but keep them clearly separated from scientific and technical experts" (informal discussion with a scientist belonging to the French delegation).

Our observation of the Panama conference shows that the issue of traditional knowledge in fact deeply divided the scientific community itself. For instance, official discussions showed that the French scientific delegates wanted a neat separation between scientists and traditional knowledge holders, whereas the delegates from other EU countries were in favor of mixing them. Informal discussions suggested that, in addition to national cultures, those natural scientists who had participated in the creation process for a long time were more prone to accept the involvement of traditional knowledge holders than those more recently engaged. Social scientists were also more in favor of including traditional knowledge holders than natural scientists.

\section{Techniques of inclusiveness}

At the opening of the Panama conference, Chair Bob Watson declared: "We need to be open-minded. We need to find a suitable way to satisfy everybody." The goal of satisfying everybody, or having everybody on board, was asserted a number of times, especially through the repetition of the motto "nothing is agreed until everything is agreed" that played a key role in opening up the process to its very end and preventing potentially disappointed participants from leaving. In fact the chairman and the UNEP representatives in charge of the secretariat of the conference did not only seek to ease the tensions. They also used some of them to demonstrate that they were actually building an inclusive organization. We found that the capacity to handle the tensions so as to demonstrate the inclusiveness of the institutionalization process was a major strategy displayed by the chairman. We shall illustrate the various techniques of inclusiveness implemented on the spot by the chairman, leaning on his experience, his leading position, and his intuition and knowledge of the diversity of opinions and interests among the participants and of their relative capacity to block the negotiation process (Box 1).

\section{Box 1:}

Bob Watson, an experienced institutional entrepreneur of environmental governance

Bob Watson is a British scientist born in 1948. He led a distinguished scientific career in environmental sciences with a broad range of institutional responsibilities in various organizations. In particular, he chaired the Global Biodiversity Assessment in the early 1990s and the IPCC from 1997 to 2002 , 
and cochaired the MA from 2001 to 2005 . He was also involved in the executive committee of the IMoSEB and strongly pushed in favor of the creation of a new platform of biodiversity and ecosystem assessment. He was led to chair the IPBES conferences from 2010 (Busan conference) onward because of his scientific legitimacy and his knowledge of a number of previous successful ESPIs (especially the IPCC, which is considered a model by many biodiversity scientists).

\section{Avoiding blockage from powerful actors and advancing the process}

Chair Bob Watson played a crucial role in preventing scientists from withdrawing out of fear of getting stuck in an endless process, while also preventing government representatives from withdrawing out ot fear of allowing premature and undesirable agreements. Hence, there was a fragile and uneasy balance between moments when the creation process was slowed down, to reassure government representatives, and moments when it was speeded up, to reassure scientists. Throughout the week, the chairman reaffirmed the need for the IPBES to be established in Panama, answering, for instance, to the above-mentioned declaration of the Bolivia representative:

This is the fifth meeting to establish the IPBES. We've had three consultative meetings and two meetings after we were asked by the UN General Assembly to establish the platform; we can keep talking forever, there's some sense to moving ahead. (Panama conference, plenary session, April 19, 2012)

He alternately urged the participants to make progress ("I beg you to be flexible!") and assured the government representatives that "we will take all the time needed." Toward that goal, extra time was added for discussion through evening sessions, earlier sessions in the morning, and inter-sessional work to examine issues that had been sidelined.

Other ways of achieving agreements on the creation of the organization before the end of the conference were used by the chair, while also providing sufficient time for discussions and objections. These ways included the chair making suggestions about different issues (for instance, the provisory composition of the multidisciplinary expert panel), and him deciding to leave aside some questions, including both minor and blocking issues that were left bracketed provided they would not lead to the blockage of the whole creation process. For instance, regarding the regionalization and to avoid a blockage, the chair suggested a provisional arrangement that consisted of establishing an interim expert panel to address the criteria of regionalization in further meetings. The chair relied on his estimation of the participants' respective weight at each point of the process to identify potential points:

If China and other countries block the interim multidisciplinary expert panel right at the beginning, I'll drop the subject. If only Bolivia blocks, I will try and deal with it. (Panama conference, EU coordination meeting, April 20, 2012)

\section{Distributing satisfactions}

Concerning the forms of knowledge, the strategy was to distribute the satisfactions equally and to show that the negotiations were taking all options into account. For instance, in the EU coordination meeting a scientist belonging to the Danish delegation clearly illustrated the will to satisfy the promoters of a purely scientific approach and the promoters of the inclusion of traditional knowledge holders in turn:

We gave the scientists something to chew on [by reassuring them that the IPBES would address scientific issues], so it's nice if we give the people interested in traditional knowledge also something to chew on. (Panama conference, EU coordination meeting, April 15, 2012).

Another way of distributing satisfactions consisted of favoring the broadest possible perspective, i.e., the inclusion of various forms of knowledge. Against proponents of the name "scientific panel," the chair strongly advocated for a name that would not rule out the possibility of involving different forms of knowledge: he considered such a ruling out to be an "incredible narrowing" (Panama conference, plenary meeting, April 19, 2012) of the approach to an IPBES. Indeed, it could have triggered the withdrawal of those representatives and scientists strongly favoring an inclusive approach, whereas inclusion of a range of knowledge forms would not exclude the promoters of peerreviewed science in the same way. The name "multidisciplinary expert panel" was eventually accepted: It allowed leaving open the possibility of mixing scientists and traditional knowledge holders, without completely settling the question. The report of the Panama conference also gives very broad guidelines for the nomination and selection of the members of the expert panel with expertise regarding "both natural and social sciences and traditional knowledge" (UNEP 2012:21).

Stabilizing shared small wins

Efforts were eventually made to stabilize shared small wins, notably by never reopening a point that had previously been agreed upon, such as the outcomes of previous meetings. Despite the notion that "nothing [was] agreed until all [was] agreed," the attempt of any participant to rediscuss a point that had already been settled immediately triggered the opposition of other participants and the chair (such as, for instance, the agreement regarding the platform having one chair and four vice-chairs, which had been achieved in the Nairobi conference). In addition, the members tended to use "crystallized" definitions and terms, such as the definition of ecosystem services released by the MA: "We have a stabilized definition. We don't have to discuss" (Panama conference, plenary meeting, April 18, 2012).

These various strategies eventually contributed to reaching the final official decision of creating the IPBES, which had been at stake since 2008, as well as to an agreement around some of its patterns and modalities of functioning (such as the principle of an expert panel including scientists and other knowledge holders) at the end of the Panama meeting. 


\section{DISCUSSION}

\section{Complicating the landscape of tensions in science-policy boundary organizations}

Our results make it firstly possible to further discuss the notion of boundary organization (BO) elaborated by Guston (1999, 2001) as an institutional arrangement considered to act as an agent between two well-identified principals, i.e., science and policy. The tensions we identified confirm that science-policy organizations involve much more complexity and plasticity than the binary boundary between science and policy would suggest. The need for better accounts of the internal heterogeneity and plasticity of the worlds of science and policy has been underlined by a range of empirical studies. For instance, Miller (2001) emphazised that science and policy are clearly not monolithic: The debates between Northern and Southern climate scientists can be just as harsh or even harsher than between climate scientists and government representatives.

In their recent study of a university-based $\mathrm{BO}$, Parker and Crona (2012) noted that BOs should not be seen as static but instead flexible and changing: The management of BOs is "an ongoing process among tensions derived from inconsistent demands ... by different stakeholders" (Parker and Crona 2012:267). They insisted that tensions are unavoidable, and a $\mathrm{BO}$ has to constantly navigate in a landcape of tensions. Here we suggest that the landscape-of-tensions model might still be too neat as regards the IPBES case. In particular, Parker and Corna (2012) identified well-defined and stable stakeholders, which they represented as clear and permanent figures in a landscape of tensions. However, what we found in the case of the IPBES was closer to moving and shifting publics (Dewey 1991 [1927]), which alternately formed and broke up according to the various issues discussed. For instance, envisaging science representatives as a unified public was relevant when we considered the temporality issue, but not the forms-of-knowledge issue. As analyzed in the case of citizen participation (Turnhout et al. 2010), participants do not preexist the process: Instead, they are shaped as distinct stakeholders by and within the participative process. In a similar way, the creation of a new ESPI involves the creation of a consistent public of participants. This requires handling a host of changing divides between participants depending on the issues and tensions at stake to achieve as much inclusiveness as possible.

\section{The art of having everybody on board}

We come here to our second key result. Parker and Crona (2012) emphazised the variable role and weight of individuals in the management of BOs. However, like Westley et al. (2013), we think that more empirical studies are needed to scrutinize the role of individuals in transforming SESs. The role of chairpersons in environmental organizations and negotiations remains only partly documented in the literature (however, see Depledge 2007 and Tallberg 2010). In the case of the IPBES, we found that the chairman identified blocking issues and actors, suggested ways forward, pushed some solutions at the detriment of others, etc. Moreover, we found the language of the chairman to be crucial to buffering tensions and conflicts.

As emphasized by Vadrot (2014b), social-ecological changes are not purely driven by micrologics of power but also by the ways in which objects to be governed are selected and described within institutionalization processes. The chairman clearly played an important role of institutional entrepreneur by implementing a number of techniques of inclusiveness that were crucial to achieving the IPBES institutionalization. We agree with Westley et al. (2013) that the role of transformative agents in SESs is better captured through a focus on institutional entrepreneurship, meaning capacities of guiding emerging changes and seizing contextual opportunities, rather than on top-down leadership, i.e., capacities of controlling changes. The strategies used by the chairman during the IPBES negotiations (e.g., sidelining risky issues, stabilizing shared small wins, distributing satisfactions) demonstrate an art of handling both emerging opportunities and frictions by leaning on his extensive knowledge of the countries' positions and view of the global system: His "sensitivity to the dynamics of [his] own system allows [him] to work in concert with it, rather than attempt to force a direction or outcome on the system" (Westley et al. 2013:4). It is an art of managing for emergence (Lichtenstein and Plowman 2009) at the micro level of the political negotiations. We are not suggesting that the chair alone made the IPBES. We do not believe, either, that the chair was the only institutional entrepreneur involved. However, because of a range of factors (in particular, his experience in previous major environmental organizations and negotiations, his scientific legitimacy, and his power as discussion leader), he was undoubtly a decisive institutional entrepreneur in a particularly arduous process.

The incompatibility of the demands placed on the IPBES, illustrated by the above-mentioned tensions, made it impossible for the chairman to satisfy everybody, as testified by signs of annoyance and disappointment shown by some delegates regarding, for instance, the interim proposal or the broad approach to knowledge forms. Instead, he and some other IPBES promoters sought to handle the tensions so as to demonstrate that the IPBES goal was to satisfy everybody and that they were doing their best to achieve it. Here our results add to the understanding of the role of institutional entrepreneurs in the phase of building a new regime and its resilience by emphazising the importance of practices of inclusiveness, i.e., the art of handling the fragmentation of the groups of interest involved so as to guarantee the inclusiveness of the institutionalization process. Although the inclusiveness of the diverse groups and actors participating in the future institution remained partly unattainable, such techniques of inclusiveness were essential to the legitimacy and success of the IPBES creation. Constructing a new global environmental institution entailed constructing simultaneously its participants as an entity as coherent and cohesive as possible, capable of embarking on the same platform.

\section{CONCLUSION}

Innovation and adaptive capacities are currently crucially needed to build more resilient SESs (Gunderson 2010). Our study of the IPBES creation contributes to understanding the conditions of innovation in SESs by focusing on the type of agency exercised by chairpersons conducting the negotiations toward an ESPI. Strongly drawing on the ethnographic observation of the final meeting of the creation process, our results emphazise the major challenge of handling the fragmentation and plasticity of the groups of interest involved in the institutionalization process. We analyzed the efforts deployed by the IPBES promoters during the conference to prevent participants from deserting the negotiations arena and a lack of inclusiveness from discrediting 
the future institution. This enabled us to stress that creating a new global environmental institution requires the situated exercise of an art of having everybody on board through techniques of inclusiveness, thus adding to the theory of transformative agency of institutional entrepreneurs.

The final phase of the IPBES creation was an ideal observatory to identify and characterize the techniques of inclusiveness mobilized by the chairman to achieve a global agreement on the shaping of the IPBES despite the internal moving heterogeneity of the participants. However, techniques of inclusiveness are certainly at stake in the making of other international ESPIs as well, especially when it takes place under the auspices of UNEP: While the IPBES can be considered to some extent an idiosyncratic institution, its creation process was clearly influenced by the UNEP culture of negotiation and diplomacy (Ivanova 2007, 2010). The case of the IPBES creation more broadly suggests the key role of techniques of inclusiveness in enacting the globality of social-ecological changes.

Our case study finally suggests that identifying and characterizing the techniques used by institutional entrepreneurs of socialecological change require investigating the micro level of collective agency and negotiations. More socio-ethnographic empirical approaches are needed to produce grounded insights that back up and refine a theory of transformative agency in SESs at different scales.

Responses to this article can be read online at: http://www.ecologyandsociety.org/issues/responses. $\mathrm{php} / 8644$

\section{Acknowledgments:}

This research was funded by the French National Research Agency (ANR-09-SSOC-053-01). We thank all our interviewees and in particular the members of the French delegation to the Panama conference for their time and support. We are also grateful to Robert Watson, Dominique Pestre, Didier Babin, Maxime Thibon, and two anonymous reviewers for their comments and suggestions.

\section{LITERATURE CITED}

Babin, D. 2008. Strengthening the science-policy interface on biodiversity. Results of the consultative process towards an $I M o S E B$. IMoSEB final report. International Mechanism of Scientific Expertise on Biodiversity, Montpelier, France.

Barbault, R., and J.-P. Le Duc. 2005. Proceedings of the international conference on biodiversity, science and governance. Museum National d'Histoire Naturelle, Paris, France.

Biermann, F., K. Abbott, S. Andresen, K. Bäckstrand, S. Bernstein, M. M. Betsill, H. Bulkeley, B. Cashore, J. Clapp, C. Folke, A. Gupta, J. Gupta, P. M. Haas. A. Jordan, N. Kanie, T. Kluvánková-Oravská, L. Lebel, D. Liverman, J. Meadowcroft, R. B. Mitchell, P. Newell, S. Oberthur, L. Olsson, P. Pattberg, R. Sánchez-Rodríguez, H. Schroeder, A. Underdal, S. Camargo Vieira, C. Vogel, O. Young, A. Brock, and R. Zondervan. 2012.
Navigating the anthropocene: improving earth system governance. Science 335:1306-1307. http://dx.doi.org/10.1126/ science. 1217255

Callon, M. 1991. Technoeconomic networks and irreversibility. Pages 132-164 in J. Law, editor. A sociology of monsters: essays on power, technology and domination. Sociological Review monograph. Routledge, London, UK.

Clarke, A. 2005. Situational analysis. Grounded theory after the post-modern turn, Sage, Thousand Oaks, California, USA.

Crutzen, P. J. 2002. Geology of mankind. Nature 415(6867):23. http://dx.doi.org/10.1038/415023a

Depledge, J. 2007. A special relationship: chairpersons and the secretariat in the climate change negotiations. Global Environmental Politics 7:45-68. http://dx.doi.org/10.1162/ glep.2007.7.1.45

Dewey, J. 1991 (1927). The public and its problems. Swallow Press/ Ohio University Press, Athens, Ohio, USA.

DiMaggio, P. 1988. Interest and agency in institutional theory. Pages 3-22 in L. Zuker, editor. Institutional patterns and organizations: culture and environment. Ballinger, Cambridge, Massachusetts, USA.

Dorado, S. 2005. Institutional entrepreneurship, partaking, and convening. Organization Studies 26(3):385-414. http://dx.doi. org/10.1177/0170840605050873

Fligstein, N. 1997. Social skill and institutional theory. American Behavioral Scientist 40:397-405. http://dx.doi.org/10.1177/0002$\underline{764297040004003}$

Görg, C., C. Nesshöver, and A. Paulsch. 2010. A new link between biodiversity science and policy. GAIA 19:183-186.

Gunderson, L. 2010. Ecological and human community resilience in response to natural disasters. Ecology and Society 15(2):18. [online] URL: http://www.ecologyandsociety.org/vol15/iss 2/ art18/

Guston, D. H. 1999. Stabilizing the boundary between US politics and science: the role of the Office of Technology Transfer as a boundary organization. Social Studies of Science 29:87-111. http://dx.doi.org/10.1177/030631299029001004

Guston, D. H. 2001. Boundary organizations in environmental policy and science: an introduction. Science, Technology, \& Human Values 26:399-408. http://dx.doi.org/10.1177/016224390102600401

Hay, C. 2011. Interpreting interpretivism interpreting interpretations: the new hermeneutics of public administration. Public Administration 89(1):167-182. http://dx.doi.org/10.1111/ j.1467-9299.2011.01907.x

Heywood, V. H. 1995. The global biodiversity assessment. Cambridge University Press, Cambridge, UK.

Holling, C. S. 1986. The resilience of terrestrial ecosystems: local surprise and global change. Pages 292-317 in W. C. Clark and R. E. Munn, editors. Sustainable development of the biosphere. Cambridge University Press, Cambridge, UK.

Ivanova, M. 2007. Designing the United Nations Environment Programme: a story of compromise and negotiation. 
International Environmental Agreements: Politics, Law and Economics 7(4):337-361. http://dx.doi.org/10.1007/s10784-007-9052-4

Ivanova, M. 2010. UNEP in global environmental governance: design, leadership, location. Global Environmental Politics 10 (1):30-59. http://dx.doi.org/10.1162/glep.2010.10.1.30

Jasanoff, S. 1990. The fifth branch: science advisers as policy makers. Harvard University Press, Cambridge, Massachusetts, USA.

Jasanoff, S., and M. Long Martello. 2004. Earthly politics. Local and global in environmental governance. MIT Press, Cambridge, Massachusetts, USA.

Kimberly J. R. 1979. Issues in the creation of organizations: initiation, innovation, and institutionalization. Academy of Management Journal 22(3):437-457. http://dx.doi.org/10.2307/255737

Koetz, T., P. Bridgewater, S. van den Hove, and B. Siebenhüner. 2008. The role of the Subsidiary Body on Scientific, Technical and Technological Advice to the Convention on Biological Diversity as science-policy interface. Environmental Science \& Policy 11:505-516. http://dx.doi.org/10.1016/j.envsci.2008.05.001

Koetz, T., K. N. Farrell, and P. Bridgewater. 2011. Building better science-policy interfaces for international environmental governance: assessing potential within the Intergovernmental Platform for Biodiversity and Ecosystem Services. International Environmental Agreements: Politics, Law and Economics 12:1-21. http://dx.doi.org/10.1007/s10784-011-9152-Z

Larigauderie, A., and H. A. Mooney. 2010. The intergovernmental science-policy Platform on Biodiversity and Ecosystem Services: moving a step closer to an IPCC-like mechanism for biodiversity. Current Opinion in Environmental Sustainability 2:9-14. http://dx.doi.org/10.1016/j.cosust.2010.02.006

Law, J., and M. Callon 1992. The life and the death of an aircraft: a network analysis of technical change. Pages 21-52 in W. E. Bijker and J. Law, editors. Shaping technology/building society. Studies in sociotechnical change. MIT Press, Cambridge, Massachusetts, USA.

Lawrence, T. B., M. I. Winn, and P. Devereaux Jennings. 2001. The temporal dynamics of institutionalization. Academy of Management Review 26(4):624-644.

Lewis M.W., 2000. Exploring paradox: toward a more comprehensive guide. Academy of Management Review 25 (4):760-776.

Lichtenstein, B. B., and D. A. Plowman. 2009. The leadership of emergence: a complex systems leadership theory of emergence at successive organizational levels. Leadership Quarterly 20 (4):617-630. http://dx.doi.org/10.1016/j.leaqua.2009.04.006

Maguire, S., C. Hardy, and T. B. Lawrence. 2004. Institutional entrepreneurship in emerging fields: HIV/AIDS treatment advocacy in Canada. Academy of Management Journal 47 (5):657-679. http://dx.doi.org/10.2307/20159610

Millennium Ecosystem Assessment (MA). 2005. Ecosystems and human well-being: synthesis. Island Press, Washington, D.C., USA.
Miller, C. A. 2001. Hybrid management: boundary organizations, science policy, and environmental governance in the climate regime. Science, Technology, \& Human Values 26:478-500. http:// dx.doi.org/10.1177/016224390102600405

Miller, C. A. 2006. The design and management of international scientific assessments: lessons from the climate regime. Pages 187-205 in A. E. Farrell and J. Jäger, editors. Assessments of regional and global environmental risks. Resources for the Future, Washington, D.C., USA.

Nature. 2010. Wanted: an IPCC for biodiversity. Nature 465 (7298):525.

Parker, J., and B. Crona. 2012. On being all things to all people: boundary organizations and the contemporary research university. Social Studies of Science 42:262-289. http://dx.doi. org/10.1177/0306312711435833

Perrings, C., A. Duraiappah, A. Larigauderie, and H. Mooney. 2011. The biodiversity and ecosystem services science-policy interface. Science 331:1139-1140. http://dx.doi.org/10.1126/ $\underline{\text { science. } 1202400}$

Pettigrew, A. M. 1990. Longitudinal field research on change: theory and practice. Organization Science 1:267-292. http://dx. doi.org/10.1287/orsc.1.3.267

Secretariat of the Convention on Biological Diversity. 2010. Global biodiversity outlook 3. Montreal, Québec, Canada.

Tallberg, J. 2010. The power of the chair: formal leadership in international cooperation. International Studies Quarterly 54:241-265. http://dx.doi.org/10.1111/j.1468-2478.2009.00585.x

Tracey, P., N. Phillips, and O. Jarvis. 2010. Bridging institutional entrepreneurship and the creation of new organizational forms: a multilevel model. Organization Science 22(1):60-80. http://dx. doi.org/10.1287/orsc. 1090.0522

Tunón, H., M. Kvarnström, and P. Malmer. 2015. Report from the project: Indigenous and local knowledge in a scoping study for a Nordic IPBES assessment. CBM: skriftserie 96. Swedish Biodiversity Centre, Uppsala, Sweden. [online] URL: https:// www.cbd.int/doc/meetings/sbi/sbi-01/other/sbi-01-nordicilk-ipbes-2015en.pdf

Turnhout, E., S. Van Bommel, and N. Aarts. 2010. How participation creates citizens: participatory governance as performative practice. Ecology and Society 15(4):26. [online] URL: http://www.ecologyandsociety.org/vol15/iss4/art26/

Turnhout, E., B. Bloomfield, M. Hulme, J. Vogel, and B. Wynne. 2012. Conservation policy: listen to the voices of experience. Nature 488:454-455. http://dx.doi.org/10.1038/488454a

United Nations Environment Programme (UNEP). 2008. The millennium ecosystem assessment follow-up. A global strategy for turning knowledge into action. UNEP/CBD/COP/9/INF/26. Conference of the Parties to the Convention on Biological Diversity, Bonn, Germany.

United Nations Environment Programme (UNEP). 2009. Gap analysis for supporting discussion on potential establishment of an intergovernmental science policy platform on biodiversity and 
ecosystem services-preliminary report. UNEP/GC/25/INF/\#. UNEP, Nairobi, Kenya.

United Nations Environment Programme (UNEP). 2010. Report of the third ad hoc intergovernmental andmulti-stakeholder meeting on an intergovernmental science-policy platform on biodiversity and ecosystem services. UNEP/IPBES/3/3. Plenary of the Intergovernmental Science Policy Platform on Biodiversity and Ecosystem Services, Bonn, Germany.

United Nations Environment Programme (UNEP). 2012. Report of the second session of the plenary meeting to determine modalities and institutional arrangements for an intergovernmental sciencepolicy platform on biodiversity and ecosystem services. UNEP/ IPBES.MI/2/9. Plenary Meeting to Determine Modalities and Institutional Arrangements for an Intergovernmental SciencePolicy Platform on Biodiversity And Ecosystem Services, Panama City, Panama.

Vadrot, A. 2014a. The epistemic and strategic dimension of establishment of the IPBES: 'epistemic selectivities' at work. Innovation: The European Journal of Social Science Research 27 (4):361-378.

Vadrot, A. 2014b. The politics of knowledge and global biodiversity. Routledge, London, UK.

Van de Ven, A. H., and M. S. Poole. 1990. Methods for studying innovation development in the Minnesota Innovation Research Program. Organization Science 1:313-335. http://dx.doi. org/10.1287/orsc.1.3.313

Van den Hove, S., and L. Chabason. 2009. The debate on an intergovernmental science-policy platform on biodiversity and ecosystem services (IPBES). Exploring gaps and needs. IDDRIIdées pour le débat 1:1-23.

Vohland, K., M. C. Mlambo, H. L. Domeignoz Horta, B. Jonsson, A. Paulsch, and S. I. Martinez. 2011. How to ensure a credible and efficient IPBES? Environmental Science \& Policy 14:1188-1194. http://dx.doi.org/10.1016/j.envsci.2011.08.005

Watson, R. T. 2005. Turning science into policy: challenges and experiences from the science-policy interface. Philosophical Transactions of the Royal Society B 360:471-477. http://dx.doi. org/10.1098/rstb.2004.1601

Westley, F. R., O. Tjornbo, L. Schultz, P. Olsson, C. Folke, B. Crona, and Ö. Bodin. 2013. A theory of transformative agency in linked social-ecological systems. Ecology and Society 18(3):27. http://dx.doi.org/10.5751/ES-05072-180327

Young, O. R. 1991. Political leadership and regime formation: on the development of institutions in international society. International Organization 45(3):281-308. http://dx.doi.org/10.1017/ $\underline{\mathrm{s} 0020818300033117}$ 